\title{
LETTER
}

\section{Assessment scores in $\mathrm{H} 1 \mathrm{~N} 1$ infection}

\author{
Rodrigo Antonio Brandão-Neto*, Alessandra Carvalho Goulart, Alfredo Nicodemos Cruz Santana, \\ Augusto Scalabrini-Neto and Irineu Tadeu Velasco \\ See related research by Adeniji and Cusack, http://ccforum.com/content/15/1/R39
}

The usefulness of assessment scores in H1N1 patients is still undefined. The article by Adeniji and Cusack finds that the Simple Triage Scoring System (STSS) correctly predicts ICU admission and other outcomes in H1N1 patients [1]. Other scores such as the CURB-65 do not perform well in these patients [2].

We recently published our prospective series with 53 H1N1 pneumonia patients and used the SMART-COP score with good results [3]. We compared the STSS and the SMART-COP in our sample. Due to the distribution of our sample, we reported data as medians with ranges for continuous variables using the Kruskal-Wallis test and the Mann-Whitney test for the STSS and SMARTCOP scores, respectively. For categorical variables we used the chi-square test or Fisher's exact test, and the results are reported as absolute values and percentages.
Overall, the SMART-COP was a better tool for screening ICU admission and/or in-hospital case fatality compared with the STSS score in our patients with H1N1 pneumonia. The SMART-COP had higher sensibility and negative predictive values with consequently better accuracy than the STSS score: $92 \%$ versus $71.4 \%, 90.4 \%$ versus $85.7 \%$, and $83 \%$ versus $68 \%$, respectively. Results are expressed in Table 1. On the contrary, the STSS score was more specific and had a higher positive predictive value for ICU admission and/or in-hospital case fatality compared with the SMART-COP. Considering that the SMART-COP is an easy tool to use it could be combined with the STSS for better prediction of outcomes in these patients.

\section{Authors' response}

Kayode A Adeniji and Rebecca Cusack

We agree with and appreciate the comments from Brandão-Neto and colleagues concerning the SMARTCOP triage tool, which appears to show a good binary determination of mortality and ICU admission in a young (mean age 43) population of H1N1 patients at their institution.

However, we continue to assert that a triage tool needs to be applicable to all levels of triage (primary to tertiary) [1]. There will always be concern in a disaster situation that we may not have recourse to imaging and laboratory data to inform our triage instrument-guided decisionmaking. The SMART-COP requires a chest X-ray, serum albumin levels, arterial $\mathrm{pH}$ and arterial partial pressure of oxygen measurements which may limit its efficacy in

${ }^{*}$ Correspondence: rodneto@gmail.com

Department of Emergency Medicine, Hospital das Clínicas (ICHC), University of São Paulo, School of Medicine, Av. Dr. Eneas de Carvalho Aguiar, 255, 5 andar, Cerqueira César, CEP 05403-001, São Paulo, Brazil these scenarios. Charles and colleagues' original SMARTCOP paper referred to a severity-scale adjustment for primary care physicians that overlooked the need for blood results although still requiring an assessment for multilobar lung involvement [4]. It would be interesting to see whether the documented comparison of the levels of significance between the two triage tools was maintained with this adjustment in place.

The concern remains regarding what parameters a triage officer would apply to determine the disposition between two deserving patients already receiving organ support on the ICU. A staged application of situationalspecific triage tools with differing capabilities will probably be required to deliver consistent triage from the community to the ICU in a mass infection setting. We commend Brandão-Neto and colleagues in adding to this important debate for which as yet there are no definitive recommendations [3].

Abbreviations

STSS, Simple Triage Scoring System. 
Table 1. Comparison of the STSS and SMART-COP scores in 53 H1N1 pneumonia patients

\begin{tabular}{|c|c|c|c|c|c|c|c|c|}
\hline \multirow{2}{*}{$\begin{array}{l}\text { Characteristic at } \\
\text { admission and } \\
\text { hospital evaluation }\end{array}$} & \multicolumn{8}{|c|}{ Pneumonia scores } \\
\hline & $\begin{array}{c}\text { STSS } \\
\text { score } 0\end{array}$ & $\begin{array}{l}\text { STSS } \\
\text { score } 1\end{array}$ & $\begin{array}{l}\text { STSS } \\
\text { score } 2\end{array}$ & $\begin{array}{c}\text { STSS } \\
\text { score } \geq 3\end{array}$ & $\begin{array}{c}P \\
\text { value }\end{array}$ & $\begin{array}{l}\text { SMART-COP } \\
0 \text { to } 2\end{array}$ & $\begin{array}{l}\text { SMART-COP } \\
\quad \geq 3\end{array}$ & $\begin{array}{c}P \\
\text { value }\end{array}$ \\
\hline Age (years) & $30(17$ to 64$)$ & 43.5 (2 to 65$)$ & 47 (17 to 71) & 29 (25 to 64$)$ & $0.04^{*}$ & 37 (17 to 65) & 44 (17 to 71$)$ & $0.25^{* *}$ \\
\hline Male gender & $5(35.7)$ & $8(44.4)$ & $7(46.7)$ & $2(33.3)$ & $0.90^{\dagger}$ & $7(33.3)$ & $15(46.9)$ & $0.33^{\dagger}$ \\
\hline $\begin{array}{l}\text { Time from symptom onset } \\
\text { to admission (days) }\end{array}$ & $3(1$ to 10$)$ & 5 (2 to 14$)$ & $5(2$ to 10$)$ & 7 (3 to 7$)$ & $0.29^{*}$ & $4(2$ to 10$)$ & $5(1$ to 14$)$ & $0.40^{* *}$ \\
\hline Vasopressor use & - & $3(16.7)$ & $3(20)$ & $4(66.7)$ & $0.006^{+}$ & - & $10(31.3)$ & $<0.001^{\dagger}$ \\
\hline Invasive mechanical ventilation & $3(21.4)$ & $3(16.7)$ & $7(46.7)$ & $4(66.7)$ & $0.06^{\dagger}$ & $2(9.5)$ & $15(46.9)$ & $0.004^{\dagger}$ \\
\hline In-hospital case fatality & - & $1(5.6)$ & $3(20)$ & $1(16.7)$ & $0.25^{+}$ & - & $5(15.6)$ & $0.06^{+}$ \\
\hline ICU admission & $2(14.3)$ & $8(44.4)$ & $12(80)$ & $5(83.3)$ & $0.001^{\dagger}$ & $2(9.5)$ & $25(78.1)$ & $<0.001^{\dagger}$ \\
\hline $\begin{array}{l}\text { ICU admission and/or } \\
\text { in-hospital case fatality }\end{array}$ & $2(14.3)$ & $8(44.4)$ & $12(80)$ & $5(83.3)$ & $0.001^{\dagger}$ & $2(9.5)$ & $25(78.1)$ & $<0.001^{\dagger}$ \\
\hline Hospital length of stay (days) & $3(1-7)$ & $6(1$ to 25$)$ & 9 (3 to 48) & 9 (3 to 28$)$ & $0.001^{*}$ & $4(1$ to 16$)$ & $8(3$ to 48$)$ & $<0.001^{* *}$ \\
\hline
\end{tabular}

Data presented as median (range) or $n$ (\%). STSS, Simple Triage Scoring System. ${ }^{*} P$ values were obtained from the Kruskal-Wallis test for continuous variables. ${ }^{*} P$ values were obtained from the Mann-Whitney test for continuous variables. ${ }^{\dagger} P$ values were obtained from the chi-square or Fisher's exact test for categorical variables.

\section{Competing interests}

The authors declare that they have no competing interests.

Published: 5 December 2011

\section{References}

1. Adeniji KA, Cusack R: The Simple Triage Scoring System (STSS) successfully predicts mortality and critical care resource utilization in $\mathrm{H} 1 \mathrm{~N} 1$ pandemic flu: a retrospective analysis. Crit Care 2011, 15:R39.

2. Mulrennan S, Tempone SS, Ling IT, Williams SH, Gan GC, Murray RJ, Speers DJ: Pandemic influenza (H1N1) 2009 pneumonia: CURB-65 score for predicting severity and nasopharyngeal sampling for diagnosis are unreliable. PLoS One 2010, 5:e12849.

3. Brandão-Neto RA, Goulart AC, Santana ANC, Martins HS, Ribeiro SCC, Ho LY, Chiamolera M, Magri MMC, Scalabrini-Neto A, Velasco IT: The role of pneumonia scores in the emergency room in patients infected by 2009 H1N1 infection. Eur J Emerg Med 2011. [Epub ahead of print]

4. Charles PGP, Wolfe R, Whitby M, Fine MJ, Fuller AJ, Stirling R, Wright AA, Ramirez JA, Christiansen KJ, Waterer GW, Pierce RJ, Armstrong JG, Korman TM, Holmes P, Obrosky DS, Peyrani P, Johnson B, Hooy M; Australian CommunityAcquired Pneumonia Study Collaboration, Grayson ML: SMART-COP: a tool for predicting the need for intensive respiratory or vasopressor support in community-acquired pneumonia. Clin Infect Dis 2008, 47:375-384.

doi:10.1186/cc10535

Cite this article as: Brandão-Neto RA, et al:: Assessment scores in H1N1 infection. Critical Care 2011, 15:458. 